\title{
Romańskie napisy haftowane na jedwabnych pasmach z grobu nr 24 w kolegiacie w Kruszwicy*
}

Zarys treści: Artykuł stanowi analizę filologiczną i wstępną analizę epigraficzną wymienionych w tytule inskrypcji celem określenia możliwego czasu ich powstania na podstawie kryteriów epigraficznych.

Abstract: This article is a philological and initial epigraphic analysis of the titular inscriptions aimed at defining the possible time of their origin upon the basis of epigraphic criteria.

Słowa kluczowe: epigrafika romańska, romańskie tkaniny grobowe, Kruszwica, Notker Balbulus. Keywords: Romanesque epigraphy, Romanesque tomb textiles, Kruszwica, Notker Balbulus.

W grudniu 1960 r. w północnym ramieniu transeptu kolegiaty pw. św. św. Piotra i Pawła w Kruszwicy odsłonięto średniowieczny grób, który oznaczono nr. 24. W partii tułowia niekompletnego szkieletu znaleziono trzy pasma jedwabiu z inskrypcjami haftowanymi srebrną, złoconą nicią ${ }^{1}$ Pasma te, które pierwotnie prawdopodobnie miały barwę żółtą ${ }^{2}$ i stanowiły pewną całość z uwidaczniającą się sekwencją napisów, mają odpowiednio długość - 1) ok. $79 \mathrm{~cm}, 2)$ ok. $70 \mathrm{~cm}, 3)$ ok. $13 \mathrm{~cm}$ i szerokość ok. $4 \mathrm{~cm}$ (nie licząc podwiniętych na lewą stronę zakładek) ${ }^{4}$. Inskrypcje wyhaftowano w układzie

\footnotetext{
* Celem niniejszej wypowiedzi jest wstępna analiza epigrafiki zabytku. Uwagi dotyczące zarówno grafii napisów, jak również cech formalnych samych pasem mogą mieć znaczenie dla interpretacji ich pierwotnego kształtu i zastosowania. Zasadniczo jednak autor w tej ostatniej kwestii nie zajmuje stanowiska.

${ }^{1}$ Zob. J. Kürbis, Inskrypcje (Polska), w: Słownik starożytności słowiańskich, t. 2, s. 273 i w niniejszym tomie: E. Dąbrowska, Nieznane groby średniowiecznych duchownych z kolegiaty pw. św. św. Piotra i Pawła w Kruszwicy, il. 1-2. Część obiektu, która znajdowała się pod ciałem, miała ulec całkowitej destrukcji (zob. E. Springer, L'étole du haut Moyen Age trouvée à Kruszwica, „Archaeologia Polona”, 6, 1964, s. 338-339; M. Cybulska, E. Mianowska-Orlińska, Analysis, Reconstruction and Interpretation of Two Early Medieval Embroideries from Kruszwica, w: Aspects of the Design, Production and Use of Textiles and Clothing from the Bronze Age to the Early Modern Era. NESAT XII. The North European Symposium of Archaeological Textiles 21st - 24th May 2014 in Hallstatt, Austria, ed. by K. Grömer and F. Pritchard, Budapest 2015, s. 313).

${ }^{2}$ Deseń tej tkaniny widoczny pod światło na lepiej zachowanych dłuższych pasmach przypomina motyw Drzewa cnót uwidoczniony na tzw. Drzwiach Płockich z pocz. 2 poł. XII w. w kwaterze z przedstawieniem psychomachii (triumfu cnót nad wadami), zob. R. Knapiński, Credo Apostolorum w romańskich Drzwiach Płockich, Płock 1992, il. 103, 142).

${ }^{3}$ Odwołujemy się tu do numerów napisów w zamieszczonej poniżej ich edycji. Ich kolejność zgodna jest $\mathrm{z}$ układem pasem w kartonowej kasecie, w której są one przechowywane w Muzeum Narodowym w Warszawie jako depozyt Instytutu Historii Kultury Materialnej PAN (obecnie Instytut Archeologii i Etnologii PAN), sygn. Dep. 2741/2 a-c (zob. il. 1).

${ }^{4}$ Podajemy tu orientacyjne wymiary na użytek niniejszych rozważań na podstawie pomiarów podanych w artykule: M. Cybulska, E. Mianowska-Orlińska, Analysis, s. 313. Należy zwrócić uwagę, że wymiary te, ze względu na rozciągnięcia czy skurczenia materii, która przetrwała w wyjątkowo niekorzystnych warunkach powodują, że opisuję zdestruowany i wyraźnie zdeformowany obiekt w przybliżeniu. Po jego autopsji dodajmy, że zakładki dłuższych krawędzi pasem mają po lewej stronie ok. 0,5-0,8 cm szerokości. Na początku pasma z napisem $\mathrm{nr} 1$, na jego krótszej krawędzi przed słowem ISTIS zachowała się zakładka szerokości ok. $0,8 \mathrm{~cm}$, być może jako miejsce doszycia pasma lub jego łączenia
} 


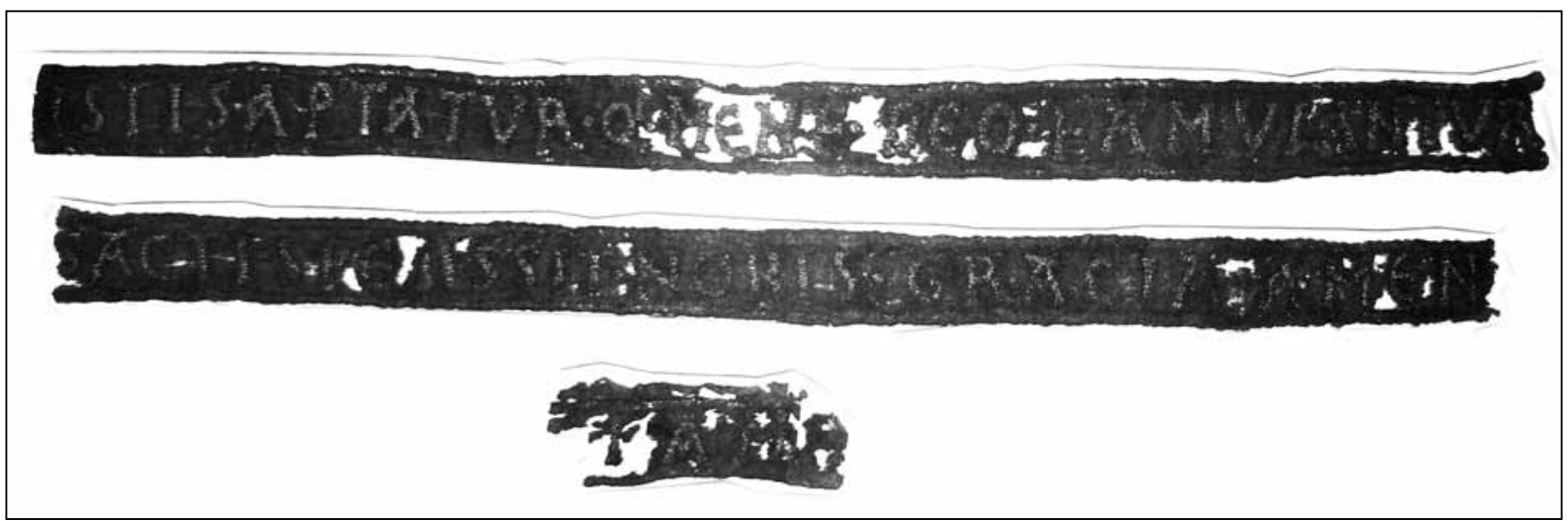

1. Pasma jedwabne z inskrypcjami, z grobu nr 24 w kolegiacie św.św. Piotra i Pawła w Kruszwicy (depozyt Instytutu Archeologii i Etnologii PAN w Muzeum Narodowym w Warszawie, sygn. Dep. 2741/2 a-c), stan obecny, fot. M.A. Janicki

horyzontalnym. Wzdłużne krawędzie pasem, podłożone na lewą stronę, na całej długości obszyto haftem wykonanym tą samą złoconą nicią. Stworzono w ten sposób kontur-obramienie pola napisu, pozostawiając pomiędzy obszyciem brzegów a napisem światło ok. $0,5 \mathrm{~cm}$ u góry i ok. $0,7 \mathrm{~cm}$ u dołu. Ujęcie pola inskrypcji haftowanym obszyciem oraz rozmierzenie napisów upodabnia pasma do tzw. filakterii (banderoli) występujących zarówno w iluminacjach kodeksów, jak również na przedmiotach romańskiej metaloplastyki ${ }^{5}$. Napisy wyszyto kapitałą romańską z elementami uncjały. Wysokość liter jest zróżnicowana i zawiera się w przedziale 2-3,5 cm. Inskrypcje starano się rozmierzyć przejrzyście. Zastosowano przy tym znaki rozdzielające w formie interpunktusów (o średnicy ok. $0,4 \mathrm{~cm}$ ), a ponadto kontrakcje, jedną ligaturę i zabieg literniczy zbliżony do enklawy — nadpisanie pomniejszonego $I$ tuż nad poprzedzającym $Q$, jeszcze w polu tej litery, którego zasięg wyznacza jej charakterystyczny ogonek.

Warto na początku zaznaczyć, że napisy zachowane na dłuższych pasmach o zbliżonej długości stanowią całostki wersyfikacyjno-rytmiczne. W pierwszym z nich nie zaznaczono kontrakcji formy liczby mnogiej famula(n)tur (jest: FAMVLATVR), co zniekształca rytmikę napisu. W drugim wprowadzono błędną kontrakcję słowa spiritus (SPE zamiast SPS). Ten błąd zdaje się wskazywać na wykonawstwo naśladowcze, pozbawione świadomości znaczenia tekstów i pozbawione również korygującej kontroli. Można domniemywać, że wspomniane zabiegi epigraficzne miały służyć przynajmniej względnemu optycznemu wyrównaniu długości napisów i noszących je pasem, w związku z możliwością ich eksponowania w układzie paralelnym — wertykalnym bądź sekwencyjnym — horyzontalnym. Wobec znacznej destrukcji trzeciego fragmentu tkaniny, pierwotnie być może zbliżonego długością do pozostałych, nie sposób określić jego miejsca w układzie napisów.

z innym pasmem bądź większą tkaniną. Miejsca takie odnotowała również Brygida Kürbis, która w liście do Aleksandra Gieysztora z 3 stycznia 1961 r. (emendujemy niewątpliwie błędną w oryginale listu datę roczną „1960”), informując go o znalezisku w Kruszwicy, zamieściła szkic wszystkich trzech fragmentów z krótkimi objaśnieniami (zob. il. 2). Oryginał listu w spuściźnie Aleksandra Gieysztora, w zbiorach Zakładu Nauk Pomocniczych i Metodologii Historii Instytutu Historycznego Uniwersytetu Warszawskiego odnalazł i wskazał mi dr hab. Piotr Węcowski (IH UW), któremu składam tu gorące podziękowanie.

${ }_{5}$ Przykładem takiego obiektu może być przenośny ołtarzyk z drewna obitego miedzianą, złoconą blachą (sygnowany przez Eilberta z Kolonii, wykonany pomiędzy 1150 a 1160 r.) z przedstawieniem Chrystusa na majestacie, otoczonego wizerunkami Dwunastu Apostołów, którzy trzymają bardzo szerokie niekiedy banderole z napisami orientowanymi pionowo bądź horyzontalnie, stosownie do ułożenia samego pola inskrypcji (por. R. Knapiński, Credo, s. 51 i il. 18). Pismo grawerowane XII w. najwcześniej poddało się nowym, gotycyzującym trendom, zjawiającym się w piśmie kodeksowym i kancelaryjnym (zob. B. Trelińska, Gotyckie pismo epigraficzne w Polsce, Lublin 1991, s. 18). 


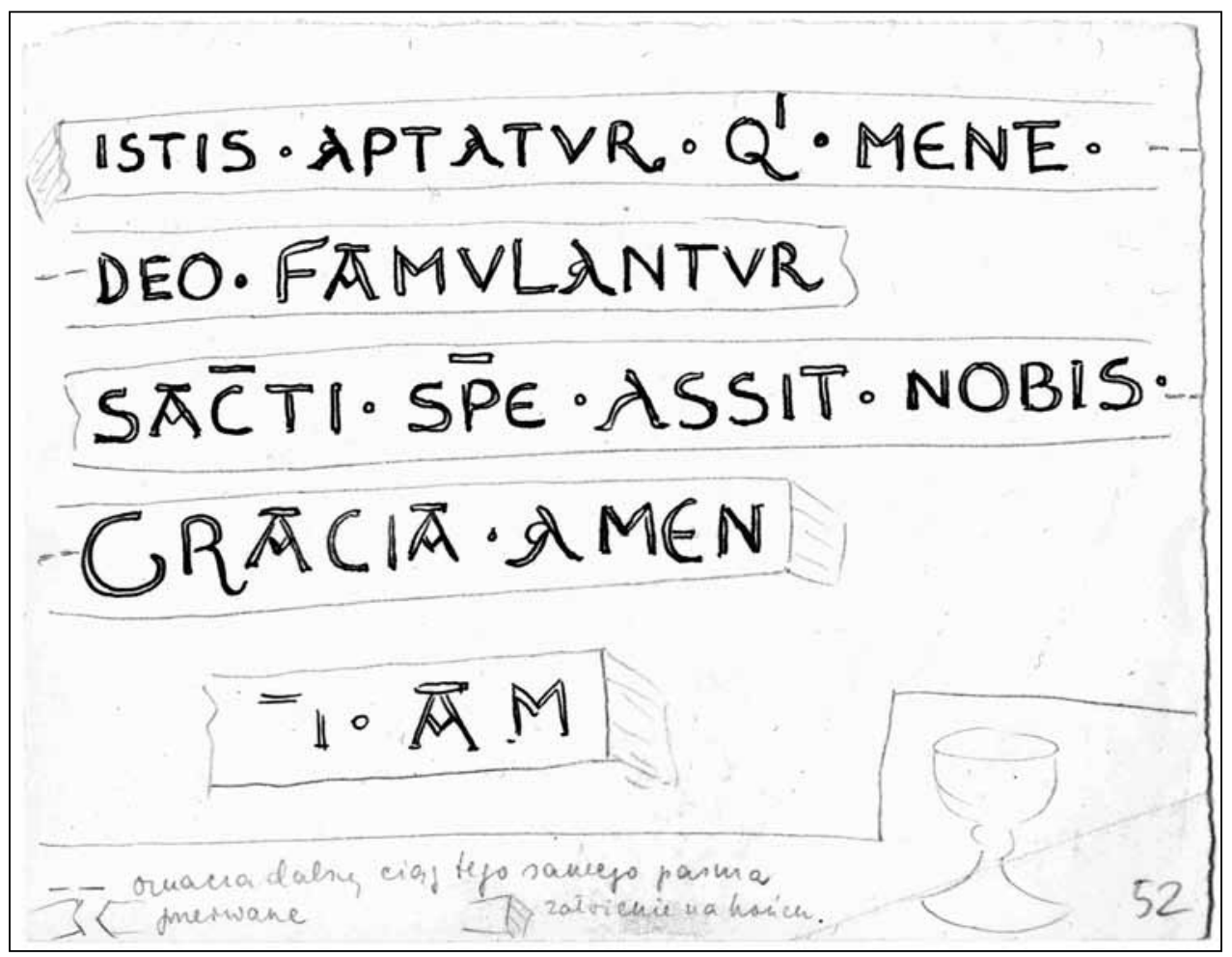

2. Przerys inskrypcji z grobu nr 24 w kolegiacie św.św. Piotra i Pawła wykonany przez Brygidę Kürbis i przesłany Aleksandrowi Gieysztorowi w styczniu 1961 r. (Zakład Nauk Pomocniczych i Metodologii Historii IH UW, Materiały Aleksandra Gieysztora), fot. M.A. Janicki

\section{Edycja napisów}

Edycja rejestruje obecny stan zachowania zabytku (il. 1) ${ }^{6}$ z uwzględnieniem w komentarzach informacji zawartych w odrysie, który towarzyszy listowi Brygidy Kürbis do Aleksandra Gieysztora ze stycznia 1961 r. (il. 2) oraz w późniejszym zapewne (niedatowanym) odrysie zabytku we fragmentach, przekazanym A. Gieysztorowi w postaci fotogramów zachowanych w jego materiałach warsztatowych?

\section{Transliteracja}

Grafia transliteracji nie uwzględnia znaków skrócenia, nadpisania w niby enklawie i ligatury. Nawias $<>$ oznacza koniektury w miejscu fragmentarycznie zachowanego znaku.

\section{Napis 1: \\ ISTIS $\cdot$ APTATVR $\cdot$ QI $\cdot$ MENTE $\cdot$ DEO $\cdot$ FAMVLANTVR}

Uwagi: $A P T A T V R$ - niezaznaczona kontrakcja nad drugim $A ; Q I-I$ w pomniejszonym module nadpisane w polu $Q$ (za literą); MENTE — ligatura $T E$.

\footnotetext{
${ }^{6}$ Za pomoc organizacyjną i techniczną, umożliwiającą objerzenie oryginału w 2013 i ponownie w 2016 r. przy użyciu specjalistycznego sprzętu dziękuję Pani kustosz Ewie Orlińskiej-Mianowskiej z Muzeum Narodowego w Warszawie, a Pani dr inż. Marii Cybulskiej z Instytutu Architektury Tekstyliów Politechniki Łódzkiej za udostępnienie wysokiej jakości skanu najkrótszego z zachowanych pasem.

7 Odrysy te, odnalezione przez dr. hab. Piotra Węcowskiego, podobnie jak list B. Kürbis, przechowywane są w zbiorach Zakładu Nauk Pomocniczych i Metodologii Historii IH UW. Por. w niniejszym tekście przyp. 4.
} 
Napis 2:

\section{$\mathrm{SACTI} \cdot \mathrm{SPE} \quad \mathrm{ASSIT} \cdot \mathrm{NOBIS} \cdot \mathrm{GRACIA} \cdot \mathrm{AMEN}$}

Uwagi: $S A C T I$ — nad $C$ słabo widoczna belka oznaczająca kontrakcję; $S P E$ — nad PE belka kontrakcji; po tej błędnie zapisanej kontrakcji słowa spiritus dziura, która objęła zapewne obecny pierwotnie interpunktus zaznaczony na przerysie autorstwa B. Kürbis.

$$
\begin{gathered}
\text { Napis 3: } \\
<\text { C }>\text { IAM [lub] }<\text { G }>\text { IAM } \\
\text { względnie: } \\
<\text { C }>\text { I } \quad \text { AM [lub] }<\text { E }>\text { I AM }
\end{gathered}
$$

Uwagi: Najkrótsze z zachowanych pasem jest znacznie zdestruowane. Widoczne są na nim wyraźnie litery $I A M$, a przed nimi jeszcze niedostrzegany wcześniej fragment górnego łuku-barku litery, zakończony, jak się wydaje, rozdwojonym szeryfem (co wobec destrukcji fragmentu trudno interpretować jednoznacznie). Szerokość łuku zachowanego górnego fragmentu litery kieruje uwagę ku takim znakom, jak $C, E$ (uncjalne) oraz $G$, z wykluczeniem z miejsca $S$ ze względu na jego wąską, ścieśnioną formę o wewnętrznych krzywiznach wykreślonych na okręgu o niewielkiej średnicy, zbliżonej do średnicy interpunktusów. Poza kryteriami epigraficznymi o interpretacji owego łukowatego fragmentu jako części konkretnej litery muszą decydować względy słowotwórcze, tzn. możliwość pojawienia się w sąsiedztwie owych dobrze zachowanych liter konkretnego znaku współtworzącego cząstkę łacińskiego wyrazu. Interpretację najkrótszego fragmentu komplikują inne jeszcze okoliczności. Pomiędzy I i A nastąpił znaczny ubytek materii stanowiącej podkład napisu. W pobliżu litery $A$, na wysokości, w której w zachowanych lepiej dłuższych pasmach widnieją interpunktusy, wyokrąglony kształt i rozmiar krawędzi wspomnianego ubytku nasuwa przypuszczenie, że również w tym miejscu interpunktus mógł się znajdować, a srebrny haft, który go tworzył, zniknął z tego miejsca wraz ze znaczną częścią materii podkładu w wyniku być może mechanicznego uszkodzenia. Jakkolwiek opisany ślad położony jest bliżej litery $A$ niż I, trzeba zwrócić uwagę, że na zachowanych fragmentach nie zawsze mamy do czynienia $\mathrm{z}$ idealnym rozmierzeniem interpunktusów, co widać w napisie $\mathrm{nr}$ 2, w którym interpunktus pomiędzy słowami NOBIS GRATIA jest wyraźnie przesunięty w stronę litery $S$. W opisywanym miejscu najkrótszego pasma sugestia obecności tam interpunktusu wynika wprost z cytowanego odrysu autorstwa B. Kürbis, na którym pomiędzy literami I i A został on wyraźnie zaznaczony, przy czym bliżej nierozpoznanego przez Kürbis $I$ aniżeli $A$. Interpunktusu tego brak natomiast na późniejszym, powiększonym odrysie z materiałów A. Gieysztora. Ponadto, według odrysu B. Kürbis na końcu omawianego fragmentu miałoby się znajdować „założenie” (zakładka materiału). Zwróćmy też uwagę, że po literze $M$ zarówno w oryginale, jak również na większym odrysie z materiałów A. Gieysztora widoczny jest ubytek, którego kształt w połowie wysokości litery $M$ mógłby sugerować również tam obecność interpunktusu.

Wobec niejednoznaczności wynikających z jednej strony z obecnego stanu obiektu, z drugiej zaś ze świadectwa rejestrującego jego wygląd wkrótce po odkryciu, a także wobec niedostrzeganego wcześniej, łukowatego fragmentu górnej części litery poprzedzającego $I$, wreszcie zaś w związku z prawdopodobieństwem zidentyfikowania w przyszłości analogicznego obiektu czy przynajmniej zespołu analogicznych napisów przedstawiamy dwojaką możliwość odczytania znaków na najkrótszym paśmie.

Jeżeli uznamy zasadność odczytania zachowanej grupy liter z poprzedzającym ją fragmentem jako $<\mathrm{G}>$ IAM względnie $<\mathrm{C}>\mathrm{IAM}$, to ze względu na możliwość domyślania się $\mathrm{w}$ tej cząstce zakończenia form akuzatiwu I deklinacji powinniśmy zwrócić uwagę na takie formy akuzatiwu, jak egregiam, graciam, potenciam czy sapienciam. Jeżeli natomiast uznamy za prawdopodobną obecność 
interpunktusu pomiędzy $I$ a $A M$, to względy słowotwórcze dopuszczają domyślanie się w szczątkowo zachowanym znaku przed $I$ chyba jedynie $C$ lub $E$ (uncjalnego).

W interpretacji zachowanej na trzecim paśmie grupy znaków nie powinien uchodzić uwadze fakt, że w przypadku napisów na obydwu dłuższych pasmach mamy do czynienia z zamkniętymi całostkami wersyfikacyjnymi (por. niżej komentarze do transkrypcji). W przypadku napisu nr 2 inicjalny wers znanego utworu zamknięty został dodanym słowem amen. Można zatem przypuszczać, że podobny charakter znaczeniowej całostki miał również napis na trzecim zachowanym fragmentarycznie paśmie. $Z$ tych i z podnoszonych wyżej powodów epigraficznych można wątpić w to, że interesująca nas grupa znaków napisu nr 3 musiała być zamknięta po $M$ interpunktusem i że poprzedzała bezpośrednio napis $\mathrm{nr} 2$, jak przedstawiono to na rekonstrukcji opublikowanej w $2015 \mathrm{r}^{8}$

\section{Transkrypcja}

Skrócenia rozwiązano bez ich oznaczenia. Nawias $<>$ oznacza tu emendację w miejscu niezaznaczonej kontrakcji (Napis 1) i błędnego znaku w kontrakcji (Napis 2). Trzema kropkami oznaczono nieznany rdzeń wyrazu, z którego zachowała się końcówka i możliwą kontynuację wyrazu następnego.

Napis 1:

Istis apta $<\mathrm{n}>$ tur, qui mente Deo famulantur

Komentarz: Napis stanowi całostkę rytmiczną, tzw. leonin bogaty9 . Nie udało się tymczasem odnaleźć jego źródła, względnie odpowiednika. Treść zdaje się wskazywać na paramenta, z którymi był związany: 'Przygotowane (przysposobione) dla tych/stosowne tym, którzy umysłem służą Bogu'.

Napis 2:

Sancti spiritu $<\mathrm{S}>$ assit nobis gracia. Amen

Komentarz: Napis stanowi pierwszy wers sekwencji na święto zesłania Ducha Świętego („Niech łaska Ducha Świętego będzie z nami...”). Za jej autora uważany jest Notker Balbulus (ok. 840-912) z Sankt Gallen, któremu przypisuje się ponadto kilkadziesiąt innych sekwencji rozpowszechnionych w całej Europie łacińskiej ${ }^{10}$. W 1926 r. James M. Clark wymieniał (za Analecta Hymnica Medii Aevi) 66 rękopisów zawierających sekwencję Notkera na dzień Pięćdziesiątnicy, zaznaczając przy tym, że zapewne ową liczbę można by podwoić, gdyż ta właśnie sekwencja należała do najbardziej rozpowszechnionych — od Dublina po Florencję. W Rzymie wykonywano ją w obecności papieża, przy czym za Innocentego III, w 1215 r. okazało się, że imię twórcy słów i melodii zostało w Sankt Gallen niemal zapomniane ${ }^{11}$.

Następujące po inwokacji do łaski Ducha Świętego Amen sugeruje, że pasmo z tym napisem zamykało sekwencję inskrypcji, którą być może rozpoczynał napis pierwszy, gdy fragmentarycznie zachowany napis trzeci mógł zawierać się w środkowym ogniwie układu (por. wyżej uwagi dotyczące transliteracji napisu $\mathrm{nr} 3$ ).

\footnotetext{
${ }^{8}$ Por. M. Cybulska, E. Mianowska-Orlińska, Analysis, s. 317, fig. 30.5.

9 Por. R. Favreau, Épigraphie médiévale, Turnhout 1997, s. 100-101. Za konsultacje prozodyczne napisu dziękuję tu osobno Dr hab. Annie Skolimowskiej z Wydziału „Artes Liberales” Uniwersytetu Warszawskiego oraz Mgr. Tomaszowi Płóciennikowi z Instytutu Archeologii UW.

10 J.M. Clark, The Abbey of St Gall as a Centre of Literature and Art, Cambridge University Press 1926, s. 184-187, por. Budapest, Országos Széchényi Könyvtár, Cod. lat. 3 (Boetius, kodeks z poł. IX w.), k. 1r (<http://bibliotheca-laureshamensis-digital.de/view/oszk_clmae3/0003> [dostęp: styczeń 2016]). Początkowe wersy sekwencji brzmią: „Sancti spiritus \| assit nobis gratia, || Quae corda nostra sibi || faciat habitaculum || Expulsis inde cunctis || vitiis spiritalibus"||, Analecta Hymnica Medii Aevi, hrsg v. C. Blume, t. 53, Leipzig 1911, nr 70, s. 119.

11 J.M. Clark, The Abbey, s. 189-190, 200, por. Analecta Hymnica, t. 53, s. 119-121.
} 
Napis 3:

...ciam [lub] ...giam

względnie:

...ci am... [lub] ...ei am...

\section{Uwagi o grafii inskrypcji}

Kapitała i po części uncjała, którą wyhaftowano napisy, mieści się w kanonie romańskiego pisma kodeksowego i epigraficznego. Heterogeniczność stylowa liter przy niedostatku analogicznych zabytków a jednocześnie mnogości epigraficznego i kodeksowego materiału porównawczego, który można przywołać dla poszczególnych znaków, zdecydowanie utrudniają precyzyjne datowanie na podstawie kryteriów stylistycznych pisma ${ }^{12}$. Zwracamy tu zatem uwagę jedynie na ważniejsze cechy liternictwa omawianych napisów.

Charakterystyczne dla romańskiego uzusu pisma majuskułowego (nie tylko w epigrafice) jest zastosowanie w obrębie jednej inskrypcji znaków kapitałowych i uncjalnych z wariantami graficznymi tej samej litery, jak widzimy to w omawianych napisach w przypadku litery $A$. W napisie nr 1 pojawia się ona trzykrotnie w formie uncjalnej, $\mathrm{z}$ charakterystycznym brzuszkiem osadzonym na lewej krokiewce litery, a ponadto raz $\mathrm{w}$ formie kapitałowej $\mathrm{z}$ charakterystycznym daszkiem i przełamaną do dołu belką. W napisie nr 2 przeważa obecność $A$ kapitałowego nad uncjalnym w stosunku 3 do 2, przy czym warto zwrócić uwagę, że $A$ rozpoczynające wyrazy w obydwu dłuższych napisach ma formę uncjalną. $A$ w problematycznym napisie-fragmencie nr 3 jest kapitałowe. Kształt $A$ w słowach aptatur, famulantur, assit i amen zbliżony jest do spotykanego w uncjale kodeksowej, a jego przykłady możemy wskazać przynajmniej od IV do IX w. ${ }^{13}$ Forma tej litery (wywodzącej się z majuskuły kursywnej ${ }^{14}$ i rzymskiej kapitały kodeksowej ${ }^{15}$ ) wykształciła się z charakterystycznym brzuszkiem na lewej krokiewce jako jeden z charakterystycznych dla uncjały znaków „nienależących ani do kapitały, ani do minuskuły"'16. Według Rudolfa M. Kloosa uncjalne $A$ z nałożoną na lewą krokiewkę brzuszkiem pojawia się w inskrypcjach zwłaszcza między XI a pocz. XIII w. ${ }^{17}$ Kształt taki mógł być naśladowany

\footnotetext{
${ }^{12}$ Por. uwagi Brygidy Kürbis nt. możliwości weryfikacji chronologicznej romańskiego pisma epigraficznego, zachowującego „zadawnione kształty, jakie już zanikły z pisma kodeksowego” i nt. trudności badań porównawczych romańskich inskrypcji (B. Kürbis, Inskrypcja nagrobna w katedrze gnieźnieńskiej z początku XI wieku, w: eadem, Na progach historii. O świadectwach do dziejów kultury średniowiecznej, Poznań 2001, s. 311-312).

13 Zob. m.in. A. Gieysztor, Zarys dziejów pisma łacińskiego, Warszawa 1973 (wyd. 2, tamże 2009), s. 72, por. S. Knight, Historical Scripts from Classical Times to the Renaissance, New Castle, Delaware 1998, s. 35. Zob. także kodeks Praedicationes (pn.-wsch. Włochy, ok. 800, Archiwum i Biblioteka Krakowskiej Kapituły Katedralnej na Wawelu, sygn. KP 140, s. 200 (Krzyż z symbolami Ewangelistów, napis przy symbolu św. Mateusza, zob. Sztuka polska przedromańska i romańska do schyłku XIII wieku, red. M. Walicki, Dzieje sztuki polskiej, 1, Warszawa 1971, cz. 1, s. 519, il. 739, por. Źródła kultury duchowej Krakowa [katalog], Kraków 2007, s. 88). Inny przykład, zob. Ewangeliarz, Nürnberg, Germanisches Nationalmuseum, Hs. 29770 (H. Hoffmann, Buchkunst und Königtum im ottonischen und frühsalischen Reich, Stuttgart 1986, Textband, s. 297, Tafelband, Abb. 128).

${ }_{14}$ P. Cherubini, A. Pratesi, Paleografia latina. L'avventura grafica del mondo occidentale, Città del Vaticano 2010, s. 53, por. B. Bischoff, Latin Paleography. Antiquity and the Middle Ages, transl. by D. Ó Cróinín and D. Ganz, Cambridge University Press 2006, s. 66-67.

15 P. Cherubini, A. Pratesi, Paleografia latina, s. 53, 56.

${ }_{16}$ Por. P. Cherubini, A. Pratesi, Paleografia latina, s. 89, 98, fig. 1, 101, fig. 3, 104, fig. 5.

${ }_{17}$ R.M. Kloos, Einführung in die Epigraphik des Mittelalters und der frühen Neuzeit, Darmstadt 1980, s. 116, Abb. 6. Por. przykłady z Drzwi Płockich z pocz. 2 poł. XII w., R. Knapiński, Credo, il. 9-11 (przerysy), 27, 33, 63, czy też kształty pierwszego i trzeciego $A$ w ,AD ARAM” z inskrypcji haftowanej na bramowaniu ornatu datowanego na XI w. (z dwunastowiecznymi naprawami), pochodzącego z opactwa św. Piotra w Salzburgu (obecnie Boston, Museum of Fine Arts, Accession number 33.676 (zdjęcia obiektu udostępnione online: <http://www.mfa.org/collections/object/chasuble-fromthe-abbey-church-of-the-benedictine-monastery-of-saint-peter-66198> [dostęp: 30.04.2016] (za zwrócenie mi uwagi na ten obiekt dziękuję tu p. dr inż. Marii Cybulskiej z Instytutu Architektury Tekstyliów Politechniki Łódzkiej).
} 
z pisma kodeksowego ${ }^{18}$. Z kolei A w gracia, z przełamaną belką i szerokim daszkiem, jest charakterystyczne dla epigrafiki i pisma kodeksowego VIII-IX w., w tym zwłaszcza dla duktów insularnych ${ }^{19}$. $\mathrm{W}$ polskim materiale epigraficznym znajdujemy je na końcu zachowanej części pierwszego wiersza inskrypcji gnieźnieńskiej (OSSA TRIVM...), datowanej na 1 ćw. XI w., a także w ligaturze AV w kwaterze z przedstawieniem psychomachii (triumfu cnót nad wadami) na tzw. Drzwiach Płockich z początku 2. poł. XII w., jako zresztą odosobniony kształt tej w litery ${ }^{20}$. Do charakterystycznych znaków uncjalnych należy pojawiające się w napisach pięciokrotnie $E$, przy czym kapitałowy wariant tej litery w zachowanych częściach nie występuje. Według typologii Kloosa zarówno zastosowane w omawianych napisach uncjalne $A$ i $E$, jak też kapitałowe $M$ (którego krokiewki łączą się na wysokości połowy trzonków litery) i $R$ z charakterystycznie odwiniętą u dołu krokiewką bliskie są kształtom tych znaków pojawiającym się w epigrafach szczególnie między XI a początkiem XIII w. ${ }^{21} R \mathrm{w}$ opisanym kształcie zbliża się też do form obecnych w dwunastowiecznych kodeksach ${ }^{22}$. Na zabytkach z ziem Polski podobne do niego widzimy na patenie z Tumu pod Łęczycą, datowanej — jakkolwiek nie bez wątpliwości - na wiek XI, ściślej jego 2. połowę ${ }^{23}$. Widniejące w napisach z Kruszwicy dwukrotnie kapitałowe $P$ jest rzadszą formą tej litery. Linia tworząca dolną część jej brzuszka została bowiem przeciągnięta przez trzonek znaku na jego lewą stronę. Pewną analogię dla tej formy znaku widzimy w piśmie kodeksowym — w pochodzącym z końca X w. Psalterium Egberti ${ }^{24}$.

\footnotetext{
${ }_{18}$ Zob. wyżej przyp. 13.

19 P. Cherubini, A. Pratesi, Paleografia latina, s. 349, fig. 6-7, por. s. 179, fig. 8.

${ }^{20}$ K. Ciechanowski, Epigrafia romańska i wczesnogotycka w Polsce, Wrocław 1965, il. 5, s. 114; R. Knapiński, Credo, il. 9-10, 103.
}

${ }^{21}$ R.M. Kloos, Einführung in die Epigraphik, s. 166, Abb. 6 I s. 125-126. Ze względu na kształty A, $R$ por. np. Nürnberg, Germanisches Nationalmuseum, Hs. 29770 (Ewangeliarz), zob. H. Hoffmann, Buchkunst, Textband, s. 297, Tafelband, Abb. 128. W przypadku $E$ uncjalnego por. m.in. inicjalne E w Kolektarium lądzkim pochodzenia nadreńskiego (W. Semkowicz, Paleografia łacińska, wyd. 2, poprawione, Kraków 2002, s. 102, ryc. 23, s. 480, ryc. 168). Kształt $M$ i $R$ por. także na patenie z Tumu pod Łęczycą, datowanej na 2 poł. XI w. (Sztuka polska przedromańska i romańska, cz. 1, s. 594, il. 1002, cz. 2, s. 732), a także w Biblii płockiej (2 ćw. XII w., Sztuka polska przedromańska i romańska, cz. 1, s. 536, il. 800). Kształt $M$ w opisanej formie znajdujemy m.in. w Ewangeliarzu kruszwickim (2-3 tercja XII w.; liternictwo tego kodeksu w ograniczonym stopniu wykazuje podobieństwa z omawianymi napisami, zob. Sztuka polska przedromańska i romańska, cz. 1, s. 549, il. 549), a także na tzw. tympanonie Jaksy, pochodzącym z nieistniejącego kościoła św. Michała Archanioła na Ołbinie we Wrocławiu (tympanon datowany na ok. 1173-1176; analiza jego formy i epigrafiki wskazuje na koneksje franko-iberyjskie warsztatu, zob. T. Płóciennik, L'épigraphie du tympan de Iaxa à Wrocław, „Cahiers de Civilisation Médiévale”, 40, 1997, fig. 3, s. 105), na Drzwiach Płockich (Sztuka polska przedromańska i romańska, cz. 1, s. 646, il. 1168, 1171), czy też na misie brązowej ze scenami mitologicznymi z Nowego Objezierza (datowana na XI-XII w., zob. A. Janowski, S. Słowiński, Sceny mitologiczne na misie brązowej z Nowego Objezierza i źródta ich inspiracji, „Biuletyn Historii Sztuki”, 70, 2008, nr 1-2, il. 1 (przerys), s. 142, il. 9, s. 144). Podobne jak w omawianych napisach z Kruszwicy $R$ widzimy też w inskrypcjach Drzwi Płockich z początku 2 poł. XII w. (R. Knapiński, Credo, il. 7, 9-11 (przerysy), 33, 63, 147, por. Sztuka polska przedromańska i romańska, cz. 1, s. 647, il. 1174). Por. też kształt kapitałowego $R$ w powoływanej wyżej (zob. przyp. 17) inskrypcji z ornatu pochodzącego z opactwa św. Piotra w Salzburgu.

22 Por. P. Cherubini, A. Pratesi, Paleografia latina, s. 508, fig. 2.

${ }^{23}$ T. Płóciennik, Kilka uwag na temat inskrypcji gnieźnieńskiej OSSA TRIUM..., w: Architektura romańska w Polsce. Nowe odkrycia i interpretacje. Materiały z sesji naukowej w Muzeum Początków Państwa Polskiego, Gniezno, 9-11 kwietnia 2008 roku, red. T. Janiak, Gniezno 2009, s. 672-673, por. Sztuka polska przedromańska i romańska, cz. 1, s. 594, il. 1002, cz. 2, s. 732.

${ }^{24}$ Psalterium Egberti, Cividale del Friuli, Museo Archeologico Nazionale, Cod. Cap. CXXXVI Inv. 1545, k. 17r (miniatura z przedstawieniem Egberta, słowo SUSCIPIT, zob. skan rękopisu dostępny online: http://www.librideipatriarchi.it/salterio-di-egberto-codex-gertrudianus/, skan 189 [dostęp: czerwiec 2016], por. fotografię tej miniatury w wysokiej rozdzielczości, również dostępną online: https://upload.wikimedia.org/wikipedia/commons/d/d0/Egbert-Psalter\%2C_fol._17.jpg [dostęp: 30.04.2016], zob. także reprodukcje w: Sztuka polska przedromańska i romańska, cz. 1, s. 520, il. 740; Mölitwy księżnej Gertrudy z Psalterza Egberta z Kalendarzem, wyd. M.H. Malewicz, B. Kürbis, oprac. B. Kürbis, Monumenta Sacra Polonorum, 2, Kraków 2002, il. po s. 186; por. kodeks Biblioteki Uniwersyteckiej w Monachium, Cod. ms. 179 (Ps. Alcuin, De divinis officiis, zob. H. Hoffmann, Buchkunst, Textband, s. 213, Tafelband, il. 78). Można także zastanawiać się, czy użycie w napisach kruszwickich dość niezwykłej formy $P$ nie jest refleksem niewłaściwej adaptacji oznaczenia skrótu pro, jakie widzimy np. w inskrypcjach na kielichu tzw. królewskim z Trzemeszna, dziele warsztatu bawarskiego z lat 1180-1190 (zob. P. Skubiszewski, Le Règne, le Sacerdoce et la Salut. Un cycle d'images et son commentaire épigraphique sur le calice 
Enklawy i ligaturę, w tym ligaturę kapitałowych $T E$, występującą napisie 1 Kloos wymienia jako jedno z charakterystycznych zjawisk epigrafiki XI -1 poł. XII w. $^{25}$ Interpunktusy zastosowane analogicznie jak $\mathrm{w}$ omawianych napisach, acz proporcjonalnie mniejsze rozmiarem widzimy np. na tablicy grobowej biskupa Maurusa (zm. 1118) z krypty św. Leonarda katedry krakowskiej ${ }^{26}$.

Podsumowując te wstępne obserwacje w odniesieniu do kwestii czasu wykonania inskrypcji, wziąwszy pod uwagę wskazane wyżej charakterystyczne cechy zastosowanego w nich pisma, można ostrożnie datować je nie później niż w 2 połowie czy u schyłku XII w., zwłaszcza jeśli obiekt do którego omawiane napisy należą miałby być importem. Pismo inskrypcji wymaga oczywiście dalszych badań porównawczych z możliwie szerokim uwzględnieniem zachodnio- i południowoeuropejskiego materiału epigraficznego ${ }^{27}$, a także pisma kodeksowego.

\section{Romanesque Embroidered Inscriptions on Silk Fabric Strips from Grave no. 24 in the Collegiate Church in Kruszwica}

Summary: The article is a philological analysis and an initial epigraphic analysis of inscriptions embroidered on silk fabric found in 1960 in tomb no. 24 in the Romanesque collegiate church in Kruszwica. The preserved three pieces of silk (two are of identical length and one is a fragment) originally constituted probably a single object with the inscriptions arranged most likely into a sequence with a cohesive meaning (on the function of this object cf. articles by E. Dąbrowska and M. Cybulska and E. Orlińska-Mianowska in this volume). A philological analysis of the inscriptions preserved on the longer pieces of fabric makes it possible to ascertain that they comprise rhythmic-versification units. Inscription no.1 is in so-called rich hexameter, while inscription no. 2 is an incipit of a hymn to The Holy Spirit, attributed to Notker the Stammerer (Balbulus) from St. Gallen. The fragmentary inscription no. 3., barely several letters long, poses the greatest interpretation problem owing to the state of its preservation, which (according to B. Kürbis, who witnessed its discovery) could have been quite different than its present-day version. For this reason it seems possible to decipher the fragment in question in two ways, and the place which inscription no. 3. could have originally held in the sequence of inscriptions remains of a closely connected question. An epigraphic analysis of the inscriptions written in Romanesque capitals with elements of the uncial indicates their imitative execution (i.a. an error in the word: spiritus in inscription no. 2), albeit with the use of rather sophisticated lettering (the letter $P$ ). The shapes of the signs permit a restricted establishment of the time of the origin of the inscriptions, since some occur in codex writing and epigraphic much earlier than could be the date of the strips of fabric from Kruszwica ( $A$ in: gracia from inscription no. 2). By referring to a typology of Romanesque epigraphic writing presented by Rudolf M. Kloos, codex and epigraphic comparative material (which should be considerably expanded) allows us to propose an approximate time of the origin of the inscriptions as not later than the second half or the end of the twelfth century, especially if the object to which the discussed inscriptions belong had been imported from the West.

Nota o autorze: Mare k A. J a n i k i — adiunkt w Zakładzie Nauk Pomocniczych Historii i Metodologii Instytutu Historycznego Uniwersytetu Warszawskiego.

Zainteresowania badawcze: Polska i Litwa schyłku średniowiecza oraz wczesnej epoki nowożytnej — przemiany społeczno-polityczne i kulturowe (humanizm, reformacja, parlamentaryzm, dyplomacja, kancelaria królewska i dwór, kultura artystyczna i literacka); źródłoznawstwo i edytorstwo (zwłaszcza źródeł epistolograficznych i epigraficznych).

roman de Trzemeszno w: Qu'est-ce que nommer? L'image légendée entre monde monastique et pensée scolastique. Actes du colloque du RILMA, Institut Universitaire de France (Paris, INHA, 17-18 octobre 2008), édités par Ch. Heck, Turnhout 2010, s. 154, fig. 11, s. 155, fig. 14, s. 156, fig. 16, por. Sztuka polska przedromańska i romańska, cz. 1, s. 609, il. 1047-1049). ${ }^{25}$ R.M. Kloos, Einführung in die Epigraphik, s. 124. Ligatura TE, por. Ewangeliarz, Nürnberg, Germanisches Nationalmuseum, Hs. 29770 (zob. H. Hoffmann, Buchkunst, Textband, s. 297, Tafelband, Abb. 128).

${ }^{26}$ K. Ciechanowski, Epigrafia romańska, s. 115-116, il. 6-7.

$27 \mathrm{Z}$ pewnością należałoby omawiane napisy skonfrontować z materiałem zawartym w takich zwłaszcza wydawnictwach seryjnych jak: Die deutschen Inschriften i Corpus des Inscriptions de la France Médiévale. 
Author: Marek A. Jan icki - employed at Institute of History, University of Warsaw as an assistant professor (Auxiliary Sciences and Methodology of History Unit).

Academic interests: Poland and Lithuania in the late Middle Ages and early modern era - sociopolitical and cultural changes (humanism, the Reformation, the parliamentary system, diplomacy, the royal office and court, artistic and literary culture); studies and editing of primary sources (especially epistolographic and epigraphic sources).

Instytut Historyczny Uniwersytetu Warszawskiego, ul. Krakowskie Przedmieście 26/28, 00-927 Warszawa e-mail: janicius@gmail.com

\section{Bibliografia}

Cherubini P., Pratesi A., Paleografia latina. L'avventura grafica del mondo occidentale, Città del Vaticano 2010 Ciechanowski K., Epigrafia romańska i wczesnogotycka w Polsce, Wrocław 1965

Clark J.M., The Abbey of St Gall as a Centre of Literature and Art, Cambridge University Press 1926

Favreau R., Épigraphie médiévale, Turnhout 1997

Gieysztor A., Zarys dziejów państwa tacińskiego, Warszawa 1973, wyd. 2, tamże 2009

Hoffmann H., Buchkunst und Königtum im ottonischen und frühsalischen Reich, Stuttgart 1986

Kloos R.M., Einführung in die Epigraphik des Mittelalters und der frühen Neuzeit, Darmstadt 1980

Knapiński R., Credo Apostolorum w romańskich Drzwiach Płockich, Płock 1992

Knight S., Historical Scripts from Classical Times to the Renaissance, New Castle, Delaware 1998

Płóciennik T., Kilka uwag na temat inskrypcji gnieźnieńskiej OSSA TRIUM..., w: Architektura romańska w Polsce. Nowe odkrycia i interpretacje. Materiaty z sesji naukowej w Muzeum Poczatków Państwa Polskiego, Gniezno, 9-11 kwietnia 2008 roku, red. T. Janiak, Gniezno 2009, s. 661-667

Płóciennik T., L'épigraphie du tympan de Iaxa à Wroctaw, „Cahiers de Civilisation Médiévale”, 40, 1997

Semkowicz W., Paleografia tacińska, wyd. 2, poprawione, Kraków 2002

Skubiszewski P., Le Règne, le Sacerdoce et la Salut. Un cycle d'images et son commentaire épigraphique sur le calice roman de Trzemeszno, w: Qu'est-ce que nommer? L'image légendée entre monde monastique et pensée scolastique. Actes du colloque du RILMA, Institut Universitaire de France (Paris, INHA, 17-18 octobre 2008), édités par Ch. Heck, Turnhout 2010

Trelińska B., Gotyckie pismo epigraficzne w Polsce, Lublin 1991 